\title{
THE TURN TO VIOLENCE IN THE
}

\section{KURDISH-TURKISH CONFLICT}

\section{Using framing theory to explain why the Turkish- Kurdish conflict turned violent}

Laura Meijer

Abstract This paper analyses why the protracted conflict between the PKK and the Turkish state started in 1984. It argues that the traditional focus on ethnic grievances is insufficient to explain the turn to violence in the Kurdish-Turkish conflict. Using Desrosiers' framing theory for identity-based conflicts, this paper shows how the 1980 Turkish military coup provided the circumstances for violence to erupt. The Turkish military oppression diminished the influence of more moderate Kurdish voices, which led to the acceptance of the PKK's message that only violent measures could resolve Kurdish oppression. This enabled the mobilization of Kurds in Turkey and the diaspora and led to the eruption of violence.

\section{Introduction}

Since the summer of 2015, there has been a re-emergence of violence between the Kurdistan Workers Party (Partiya Karkerên Kurdistanê (PKK)) and the Turkish state. With attacks by the PKK on the Turkish military and bombings 
by the Turkish state on PKK-targets, the ceasefire that was established in 2013 seems to have ended (Wielgos, 2015). The renewed attacks also meant the end of the fragile peace process between the Turkish leading party, the Justice and Development Party (AKP), and the leader of the PKK, Öcalan, that had been going on for several years (Nazish, 2015).

The current violence is no new phenomenon. Already, since 1984, there has been fighting between the PKK and the Turkish state, with its peak in the 1990s. The conflict has cost over 40,000 people's lives and the displacement of many others (Marcus, 2007). After over 40 years of violence, one sometimes loses sight of the reason the violence originally erupted. In analysing this issue, different scholars have pointed at the grievances -meaning the resentment caused by feelings of being wronged- among the Kurdish population against the Turks and the Turkish state, as a result of structural discrimination against the Kurdish ethnic minority (see, among others, Yavuz, 2001; Saatci, 2002; Yegen, 2007). However, while these grievances were present from the start of the 20th century, it was only in 1984 that the Kurdish-Turkish conflict became a violent conflict. Grievances alone can thus not explain the actual start of the civil war. Moreover, there have been many moderate Kurdish organizations before 1984, which raises the question why it was in the end the PKK that was able to largely dominate the Kurdish-Turkish issue.

In order to understand what caused the Kurdish-Turkish issue to turn violent, it is therefore important to go beyond grievances alone. The framing theory for identity-based conflicts, developed by Marie-Eve Desrosiers (2015) incorporates grievances into a larger theory. It explains how changes in circumstances can lead an ethnocentric frame to be accepted by a certain population, enabling the mobilization of an ethnic group for violent actions. Using Desrosiers' theory, this paper argues that the military coup that happened in Turkey in 1980 provided the circumstances in which the PKK's frame could resonate among the Kurdish population. Due to the fact that the Turkish military, which came to power in the 1980 coup, oppressed large parts of the Kurdish population, more moderate Kurdish organizations had limited influence or even disappeared. This led to the acceptance of the PKK's message that only violent measures could solve the Kurdish oppression by (mainly young) Kurds who were already experiencing strong feelings of injustice. Moreover, due to the 1980 coup, the message of the PKK reached the Kurdish diaspora in Europe. The money that was raised among the diaspora, in combination with a mobilization of Kurds in Turkey, enabled the turn to violence in the Kurdish-Turkish conflict.

First, the theory by Desrosiers is extended upon. Secondly, it is applied to the conflict at hand, explaining first the long-existing grievances among the Kurdish 
population, then the mobilization of the Kurdish population in Turkey and lastly the mobilization abroad. This is followed by a conclusion.

\section{Framing theory explaining identity-based conflicts}

Generally, framing theory has been used as a tool for explaining the mobilization of people, for example for a protest. In her article, Desrosiers (2015) argues that framing theory, if adapted to the study of conflicts, can also be a very promising framework for explaining identity-based conflicts. Framing is the process in which "purposive tools" (Desrosiers, 2015, p. 128), called frames, are used to present people or circumstances in a specific way in order to achieve a specific goal; in the case of civil war, for example, the mobilization for ethnic violence. Importantly, not all frames result in the desired goal: a frame needs to align with public views and resonate enough in a specific population in order to achieve the intended mobilization. This is where structures and context play a role: whether frames resonate enough is often determined by the specific circumstances of that time. Changing circumstances allow for new or different frames to arise, affecting how these changes are perceived, and whether they will be perceived as opportunities by the population. In that sense, "framing is the vector that translates circumstances into recognized opportunities and actions" (Desrosiers, 2015, p. 129).

In identity-based conflicts, ethnocentric frames play a large role. These frames tap into existing feelings among members of ethnic groups about belonging, rights and identity, and are therefore key to ethnocentric violence. However, in order for ethnocentric framing to succeed, the circumstances need to be favourable for such a frame to resonate. Desrosiers (2015) gives examples of circumstances that can create ethnocentric rhetoric to be used: "shifting patterns of power relations [...] changes in state strength/policies, a major crisis or event, [...]" (p. 129). If there are agents making use of this (change in) circumstances to stimulate taking up arms, violence can erupt. Desrosiers stresses that not every use of ethnocentric frames necessarily leads to violence; they can also be used to mobilize identity-based solidarity that can lead to support of the ethnocentric cause. There are three types of solidarity mobilization frames: (1) injustice frames stressing the injustice done to the group, (2) adversarial frames, focusing on the righteousness of the group and the wrongfulness of the other and (3), the counter-frame, stressing how the approach of this specific group is better than any other. In order to achieve the extra step toward violence, these frames are often combined with frames of gravity, stressing the seriousness of the situation, and aptness frames, which focus on the possibility of the action to be successful. As 
will become clear in the analysis of the outbreak of the violence of the PKK, there can be several frames operating at the same time.

Figure 1 gives an overview of the different processes involved in framing theory for identity-based conflicts. In the section that follows, this framework will be used to analyse the violent eruption of the Kurdish-Turkish conflict. By combining both identity-aspects as well as (changes in) circumstances, it is possible to explain how grievances could lead to violence under the specific circumstances of the 1980s.

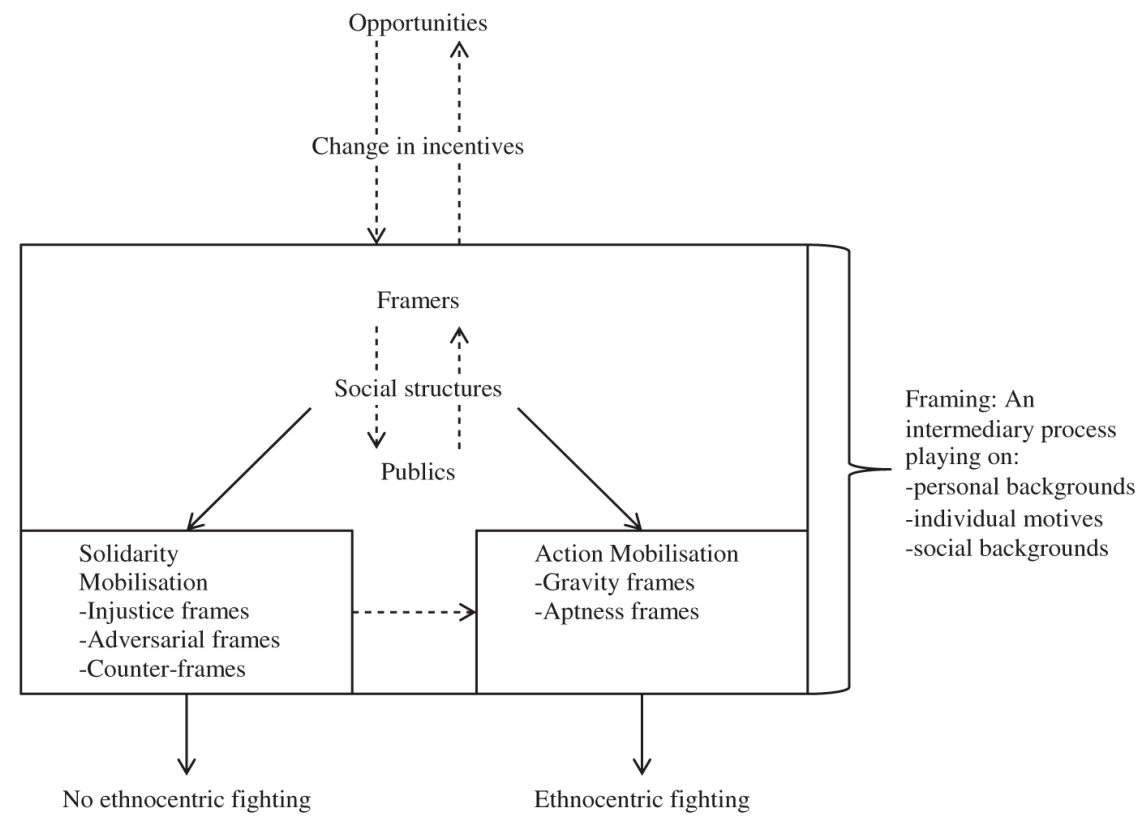

Figure I Overview of framing theory for identity-based conflicts. Reprinted from "Tackling Puzzles of Identity-Based Conflict:The Promise of Framing Theory," by M-E. Desrosiers, 20I5, Civil Wars, I 7, p. 133.

\section{Long-existing grievances among the Kurdish populations}

In order to understand the resonance of the frames presented by the PKK throughout the Kurdish population, it is important to first look at long existing grievances of the Kurdish population as this provided the basis for the PKK's call 
for violent action. When the Turkish state was formed in 1922, the south-eastern region of Turkey had a high concentration of Kurdish citizens (Aydinli, 2002). However, the founders of the Turkish Republic, instead of building upon the polyethnic heritage of the Ottoman Empire, wished to make the category of 'nation' the basis of the Turkish state, with one single identity: that of the Turk (Yegen, 2007). The strong focus on the Turkish nation was articulated in the constitution of 1924, stating that the Turkish Republic "is a nation state. It is not a multi-national state. The state does not recognize any nation other than the Turks" (in Yegen, 2007, p. 126). The exact origin of this focus on national identity remains open to discussion, but it is clear that the Turkish authorities feared that multi-ethnicity would lead to separation and potentially to the end of the Turkish Republic (Aydinli, 2002; Yavuz, 1998). The Kurdish population, the largest ethnic minority in Turkey, was seen as the most imminent threat to Turkey's unity, which led authorities to focus on the assimilation of the Kurds into the Turkish nation. Kurdish names were banned, and repressive laws of resettlement implemented in order to avoid a strong Kurdish presence in the south-eastern parts of Turkey (Kaliber \& Tocci, 2010; Tezcür, 2010). Over time, all references to Kurds as a distinct part of the population were eliminated, until "the use of the word 'Kurd' disappeared altogether from the media, and from any kind of official documentation including school textbooks" (Barkey \& Fuller, 1997, p. 64).

Next to the repression of their culture and identity, the south-east of Turkey, still mainly inhabited by the Kurds, also experienced economic deprivation in comparison to the rest of Turkey. It experienced less investment and economic growth, creating even larger grievances against the Turkish state, which seemed to ignore and neglect them (Sirkeci, 2000). The social, cultural and economic oppression of the Kurds was thus at the centre of the Kurdish-Turkish conflict: it strengthened the Kurdish self-awareness of their ethnic identity and created a feeling of Kurdish resentment of the Turkish policies, which led to tensions between the Kurds and the Turks (Barkey \& Fuller, 1997).

The existence of grievances and ethnic tension, however, does not necessarily mean that violence will erupt, especially not on this scale. Although the Kurdish identity was systematically ignored, Turkish society was still based on democratic principles allowing for the expression of dissatisfaction (Barkey \& Fuller, 1997). Indeed, as was pointed out earlier, there were many moderate Kurdish organizations that tried to achieve greater political and cultural rights for Kurds through legal and democratic means and, until 1984, no sustained violence took place. At first, the founders of the PKK were also perceived as sensation seekers more than an actual threat, and their ideas about an independent Kurdistan were not taken too seriously (Marcus, 2007). They could not count on the (Kurdish) 
locals either: instead of supporting the emergence of the PKK, the Kurdish villagers would often inform the government about the PKK's activities. Such a lack of support among the Kurdish population in the southeast would have made a guerrilla campaign extremely difficult (Barkey \& Fuller, 1997; van Bruinessen, 1988). However, within a few years, the PKK became the dominant voice in the KurdishTurkish conflict and the organization grew into a strictly coordinated guerrilla force of more than 15,000 fighters, with more than 50,000 civilian militias and a lot of active backers, also in Europe (Marcus, 2007). What caused this emergence of the PKK, leading to the outbreak of the civil war?

\section{Changing circumstances and framing opportunities - the 1980 coup}

While the grievances among the Kurdish population can be seen as structures underlying the conflict and allowing for ethnocentric framing, it was only with a change in political circumstances in Turkey that the frame of the PKK, advocating for violent action, started to resonate in the Kurdish part of society. More specifically, it was the 1980 military coup that took place in Turkey that strongly accelerated the success of the PKK in mobilizing support, both active and passive, making a violent eruption possible. In the 1960s and 1970s, Turkey had seen the emergence of much extreme left- and extreme right activism, causing chaos in society. With the 1980 coup, Turkish military leaders wanted to re-establish a stable and unitary Turkey under strong military rule (Barkey \& Fuller, 1997). Due to a general suspicion of Kurdish activism and the fact that Kurdish organizations had sometimes worked together with leftist groups, the military regime was especially harsh on Kurdish activists. It identified Kurdish nationalism as a disruptive force and aimed at its elimination. The regime introduced a highly repressive language law (Law 2932) that extended the power of the state: by prohibiting the use of the Kurdish language entirely, it could not only curb public cultural activities of the Kurds, but also those in the private sphere (Yavuz, 2001). Moreover, many Kurds suspected of activism were imprisoned under extremely bad circumstances, including torture (Gunes, 2013). The military regime hoped that by increasing the repression, the Kurdish opposition could be stopped and a Turkish unitary state could be secured. However, the oppressive actions were not able to eliminate the long-existing feelings of injustice present among the Kurdish population. What the restrictions on Kurdish expression did achieve, was that it made it impossible for any Kurd to voice their feelings of dissatisfaction with the current order in a legal or democratic way (Tezcür, 1980). 
This restriction of all aspects of Kurdish life alienated not only a large group of the Kurdish population from the state, it also brought the message of the PKK much more to the forefront (Tezcür, 1980). While earlier, the radical voice of the PKK might have sounded out of place for many Kurds, with a regime that indeed eliminated all other forms of Kurdish expression, the PKK could now portray itself as the only organization still capable of opposing state violence and defend Kurdish rights. Drawing upon existing frames of injustice done to Kurds, Kurdish violence was presented as the only effective means to achieve Kurdish socio-economic and cultural demands. As stated by Yavuz (2001, p. 12), "it [the $\mathrm{PKK}]$ presented itself as the liberation movement and voiced the desire to restore Kurdish identity and justice by violent means". While these feelings of injustice, as discussed earlier, had been existing for decades already, the PKK's addition of a counter frame, which presented violence as the sole viable solution to this injustice, only found resonance among society when circumstances allowed for it. Under the 1980 coup, Kurds were indeed experiencing the elimination of any other form of Kurdish expression, which validated the idea that violence was the only possible option left (Gunes, 2013; Tezcür, 2010).

However, as Desrosiers (2015) explained, having a frame resonate in society does not necessarily mean that people go beyond supporting it and start acting accordingly. The injustice frame and counter frame need to be complemented with frames of urgency and aptness. Again, due to the 1980 coup, this was achieved. The high levels of oppression of the state created a feeling among many Kurds that they had only two options left: either to move to Europe as refugees and start a new life, or to resort to action to remedy the situation. There was a feeling of urgency to change the situation now in order to avoid complete oppression, which was used by the PKK to recruit people to join their fight (Yavuz, 2001). While democratic means did not seem to have changed much during the past decades, the PKK offered opportunities for immediate action and heroism, which promised to have a much more direct result than the more moderate approaches. Although violence was of course not supported by all Kurds, especially among young Kurds, with a strong feeling of economic- and cultural marginalization, the message of the PKK found large resonance. It was this highly frustrated segment of the Kurdish population that was easily mobilized for actual fighting (van Bruinessen, 1998).

Thus, whereas right before the coup of 1980, the PKK had not found much backing, it now had both passive and active support among the Kurdish population. As Barkey and Fuller (1997) stated, the PKK was the only Kurdish organization for which the repressive regime had actually been a way to reverse its image, by providing the right circumstances for its message. 


\section{$5 \quad$ Framing in Europe - financial support from abroad}

The previous section outlined the mobilization by the PKK of the Kurds living in Turkey, providing the necessary human resources for its militant campaign. The message of the PKK, however, was not directed to the Kurds in Turkey only. Especially important was its influence on the Kurdish diaspora in a number of European countries; through the mobilization of the diaspora, financial- and technical assistance was assured. As with the Kurdish population in Turkey, the support by the Kurdish diaspora for violence as an answer to Kurdish oppression emerged right after the military coup in 1980. In the decades before, Kurds had moved as migrant workers to different European countries, mainly to Germany but also to France, Britain, Sweden and the Netherlands (Blätte, 2003). However, only a few of them emphasized their Kurdish identity. Instead, many were reluctant to get involved in politics and the Kurdish issue therefore did not play a large role among the diaspora communities (van Bruinessen, 1999). This drastically changed with the military coup, after which the PKK could count on large-scale support of its cause. What caused this rapid change?

There were two consequences of the military coup that made the message of the PKK find its way into Europe. Firstly, as a result of the repressive actions of the military government against the Kurdish population, a considerable group of young, politicized Kurds fled to Europe, with Germany as a key destination. These Kurds brought with them stories of the Kurdish oppression and of the PKK standing up against the Turkish state (van Bruinessen, 1998). The spread of the PKK's message throughout its diaspora was further facilitated by the European countries themselves: critical of the military coup, which was seen as resulting in deteriorating democratic values in Turkey, Europeans not only accepted Kurdish refugees but also offered them great opportunities to form organizations and networks to express their claims (Baser, 2013; Lyon \& Uçarer, 2001). The presence of the politicized and not rarely PKK affiliated Kurds "worked as a catalyst on the [diaspora] Kurd's ethnic self-awareness" and many got interested in the Kurdish cause (van Bruinessen, 1998, p. 45). In particular, second generation Kurds were highly receptive to the message brought by Kurdish refugees. Caught between their family traditions and the culture of the country they were living in, they were struggling with their identity and attracted to the idea of belonging to an ethnic community which would give their lives meaning and self-respect (Curtis, 2005; Eccarius-Kelly, 2002). The PKK, using the access to various communication channels, played into these sentiments: with its discourse on the fight for the homeland, the PKK's campaign brought a sense of belonging to second generation Kurds who had been unaware of their ethnic heritage before (Saatci, 2002; van Bruinessen, 1999). 
Thus, the 1980 coup caused the frame of the PKK, drawing upon feelings of injustice and providing violence as a solution, to reach the Kurdish diaspora in Europe. The situation of the European-Kurdish communities made them very receptive to the PKK's message and subsequently they took up their cause. This was, among others, reflected in the raising of large sums of money for PKK activities (van Bruinessen, 1998; Khayati, 2008). In combination with human resources and support in the Kurdish areas, the support coming from Europe made a large-scale eruption of violence possible. With human and monetary resources available, the actual outbreak of violence in 1984 seems no longer a surprise.

\section{Conclusion}

This paper started with raising the question of why it was only in 1984 that the Kurdish-Turkish conflict became violent and why, of all existing Kurdish organizations, it was the PKK that came to dominate the conflict. With use of the framing theory for identity-based conflicts developed by Desrosiers, it became clear that, although feelings of injustice had been existing for a long time already, it was the military coup of 1980 that made the PKK able to turn these into violent action. The very oppressive military regime provided the circumstances in which a frame of violent action against Kurdish suppression found its resonance among the population. It based its message on the already existing grievances and added to this a counter-frame, stressing that no other option than the violent one remained possible. The increased receptiveness of the Kurdish population to this message due to the repressive regime enlarged the support for the PKK and, combined with a feeling of urgency, also led Kurds to decide to join the violent struggle.

The influx of young, politicized Kurds fleeing from the repressive regime created a possibility for the PKK to get its message to the European diaspora. There, especially the Kurds of the second generation were highly receptive to the frame of the PKK, which provided them with meaning and a feeling of self-respect that they were lacking in their respective European communities. The European diaspora provided a considerable part of the funding for the struggle by the PKK. Together with the increased human resources in Turkey itself, this funding made a violent eruption of the Kurdish-Turkish conflict possible.

The explanation of the start of the conflict between the PKK and the Turkish state given here provides interesting insights into the interaction between multiple sources of conflict, such as grievances, state factors and organizations. It 
shows the multi-dimensionality of conflict and exemplifies how, among others, the actions of the state can bring about unintended outcomes due to their interaction with other forces in society. This is not only helpful in understanding the outbreak of the conflict in 1984, but can also be a useful tool for those policy-makers or researchers dealing with the current return of violence between the PKK and the Turkish state. It provides them with a multi-dimensional framework accounting for the interaction of actions by the state and the PKK, which can potentially increase the understanding of this ongoing conflict.

\section{References}

Aydinli, E. (2002). Between security and liberalization: Decoding Turkey's struggle with the PKK. Security Dialogue, 33(2), 209-225.

Barkey, H.J. \& Fuller, G.E. (1997). Turkey's Kurdish question: Critical turning points and missed opportunities. Middle East Journal, 51(1), 59-79.

Baser, B. (2013, December). The Kurdish diaspora in Europe: Identity formation and political activism. Paper presented at the Diaspora And Security Workshop. Retrieved from http://cadmus.eui. eu/bitstream/handle/1814/28337/Bahar_Baser_RR_01_2013.pdf

Blätte, A. (2003, March). The Kurdish movement ethnic mobilization and Europeanization. Paper presented at the EUSA $8^{\text {th }}$ International Biennial Conference. Retrieved from: http://aei.pitt. edu/2824/1/091.pdf

Curtis, A. (2005). Nationalism in the diaspora: A study of the Kurdish movement. Nationalism, ethnicity and conflict series. Utrecht: Universiteit Utrecht.

Desrosiers, M-E. (2015). Tackling puzzles of identity-based conflict: The promise of framing theory. Civil Wars, 17(2), 120-140.

Eccarius-Kelly, V. (2002) Political movements and leverage points: Kurdish activism in the European diaspora. Journal of Muslim Minority Affairs, 22(1), 91-118. http://dx.doi. org/10.1080/13602000220124854

Gunes, C. (2013). Explaining the PKK's mobilization of the Kurds in Turkey: Hegemony, myth and violence. Ethnopolitics, 12(3), 247-267. http://dx.doi.org/10.1080/17449057.2012.707422

Kaliber, A. \& Tocci, N. (2010). Civil society and the transformation of Turkey's Kurdish question. Security Dialogue, 41(2), 191-255.

Khayati, K. (2008). From victim diaspora to transborder citizenship? Diaspora formation and transnational relations among Kurds in France and Sweden.

Lyon, A.J. \& Uçarer, E.M. (2001). Mobilizing ethnic conflict: Kurdish separatism in Germany and the PKK. Ethnic and Racial Studies, 24(6), 925-948. http://dx.doi.org/10.1080/713766482

Marcus, A. (2007). Turkey's PKK: Rise, fall, rise again? World Policy Journal, 24(1), 75-84. 
Nazish, K. (2015). Turkey and PKK 'back to square one'. Aljazeera. Retrieved from: http://www.aljazeera.com/news/2015/07/turkey-pkk-square-150730074312972.html

Saatci, M. (2002). Nation-states and ethnic boundaries: Modern Turkish identity and TurkishKurdish conflict. Nations and Nationalism, 8(4), 549 - 564.

Sirkeci, I. (2000). Exploring the Kurdish population in the Turkish context. Genus, LVI (1-2), 149175.

Tezcür, G.M. (2010). When democratization radicalizes: The Kurdish nationalist movement in Turkey. Journal of Peace Research, 47(6), 775-789.

van Bruinessen, M. (1988). Between guerrilla war and political murder: The workers' party of Kurdistan. Middle East Report, 153, 40-42, 44-46, 50.

van Bruinessen, M. (1998). Shifting national and ethnic identities: The Kurds in Turkey and the European diaspora, Journal of Muslim Minority Affairs, 18(1), 39-52. http://dx.doi. org/10.1080/13602009808716392

van Bruinessen, M. M. (1999). The Kurds in movement: Migrations, mobilisations, communications and the globalisation of the Kurdish question (Islamic Area Studies Project Working Paper No. 14). Retrieved from:http://www.let.uu.nl/ martin.vanbruinessen/personal/publications/ index-text. html

Wielgos, A. (2015). Can war in southeastern Turkey be avoided? Foreign Policy Digest. Retrieved from: http://www.internationalpolicydigest.org/2015/11/12/can-war-in-southeastern-turkeybe-avoided/

Yavuz, M.H. (1998). A preamble to the Kurdish question: The politics of Kurdish identity. Journal of Muslim Minority Affairs, 18(1), 9-18.

Yavuz, M. H. (2001). Five stages of the construction of Kurdish nationalism in Turkey. Nationalism and Ethnic Politics, 7(3), 1-24. http://dx.doi.org/10.1080/13537110108428635

Yegen, M. (2007). Turkish nationalism and the Kurdish question. Ethnic and Racial Studies, 30(1), 119-151. http://dx.doi.org/10.1080/01419870601006603 